\section{Comparison of the Effects of an Adhesion Barrier and Chitin on Experimental Epidural Fibrosis}

\author{
Deneysel Epidural Fibroziste Adezyon \\ Bariyeri ile Chitin'in Etkinliğinin \\ Karșılaștırılması
}

\begin{abstract}
AIM: Epidural fibrosis is an important factor for postoperative failed back syndrome development and causes clinical complaints in 6-25\% of cases. An effective treatment modality has not been found yet. The aim of this study is to investigate the anti-adhesive effects of a novel agent chitin and compare these effects with a popular adhesion barrier collagen matrix.

MATERIAL and METHODS: 21 rabbits were allocated into three groups including 7 rabbits each. L5 total laminectomy was performed to all groups. No treatment was given to Group 1 (Control group). Collagen matrix was used in Group 2 and chitin was used in Group 3. Six weeks later all rabbits were sacrificed and the laminectomy areas were entirely resected and investigated histopathologically. RESULTS: He and Revel grade III epidural fibrosis was detected in the control group. Statistically significant reduction of epidural fibrosis was achieved with both of the anti-adhesive agents, collagen matrix and chitin, when compared with the control group $(\mathrm{p}<0.05)$. The results were not different between treatment groups ( $\mathrm{p}>0.05)$.

CONCLUSION: The novel agent chitin was found effective for preventing epidural fibrosis and this effect was not significantly different from the collagen matrix. In light of our findings we suggest that chitin is an effective alternative for adhesion barriers.
\end{abstract}

KEYWORDS: Adhesion barriers, Chitin, Epidural fibrosis

\section{ÖZ}

AMAÇ: Başarısız Bel Cerrahisi Sendromunun nedenlerinden biri operasyon sonrası dönemde gelişen epidural fibrozistir ve \%6-25 oranında klinik yakınmalara sebep olduğu bildirilmekte olup halen etkili bir tedavi yöntemi bulunamamıştır. Bu çalışmadaki amaç, epidural fibroziste etkinliği bildirilmiş olan kollajen matrix (DuraGen plus) gibi adezyon önleyici madde ile yeni bir ajan olan chitin etkinliğini belirlemek ve karşılaştırmaktır.

YÖNTEM ve GEREÇ: 21 adet tavşan yedişerli üç gruba ayrıldı. Gruplara L5 total laminektomi uygulandı.Birinci gruba (kontrol grubu) tedavi verilmedi. İkinci grupta laminektomi sahasına kollajen matrix, üçüncü grupta chitin uygulandı. Altı hafta sonra denekler sakrifiye edilip laminektomi alanları bir bütün olarak çıkarıldı ve histopatolojik olarak değerlendirildi.

BULGULAR: Çalışmamızda kontrol grubunda ortalama grade III epidural fibrozis tespit edildi ve epidural fibrozis çalışma gruplarında kontrol grubuna göre anlamlı olarak düşük bulundu $(p<0.05)$. Tedavi grupları kendi arasında epidural fibrozisi önlemek açısından istatiksel olarak anlamlı fark tespit edilmedi ( $\mathrm{p}>0.05)$.

SONUÇ: Yeni bir ajan olan chitinin epidural fibrozisi önlemekte etkili olduğu bulundu ve bu etkisi kollajen matriksten farklı değildi. Bu bulgular ile chitinin adezyon bariyerleri arasında bir seçenek olabileceği kanaatine varılmıştır. ANAHTAR SÖZCÜKLER: Adezyon bariyerleri, Chitin, Epidural fibrozis

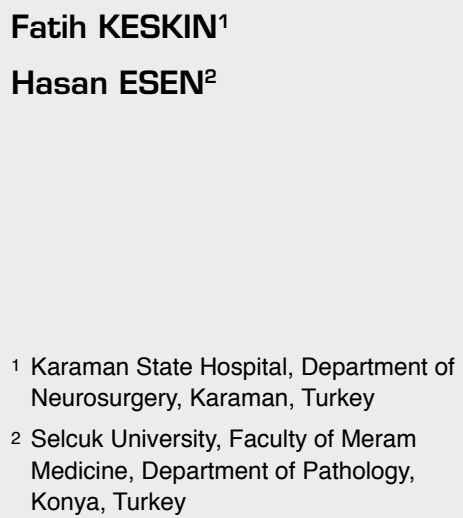

Received : 31.05.2010

Accepted : 15.06 .2010

Presented In: The 23rd Annual Scientific Congress of the Turkish Neurosurgical Society, 17-21 April, 2009, Girne, Cyprus

Correspondence address: Fatih KESKIN

Phone : +903382129567

E-mail : drfatihk@yahoo.com 


\section{INTRODUCTION}

There are many reasons of low back pain and most of them respond to medical treatment. Surgical operation is essential for some of them and a nonhealing low back pain after surgery is a serious problem for the surgeon and patient.

There are also various reasons of postoperative low back pain and fibrosis, which occurs during the physiological wound healing process when it is in excessive amounts and is called epidural fibrosis in spinal surgery $(17,18)$.

Many synthetic and organic materials such as autologous fat grafts, polytetrafluoroethylen membrane, antineoplastic agents, gelfoam, siliconecovered dacron, CO2 laser, vicryl mesh, spongostan, fibrinolytic agents, antiinflammatory agents and dural adhesion have been used to prevent or reduce epidural fibrosis formation. However, so far there is no clinically adopted treatment protocol to prevent epidural fibrosis, $(2,6,7,11,20,24,27)$.

The purpose of our study was to determine the efficacy of novel adhesion barrier chitin (SuproGel) and compare these effects with a well-known adhesion barrier collagen matrix (DuraGen plus).

\section{MATERIAL and METHODS}

This study was performed at the Kombassan Experimental and Clinical Research Center of Meram Medical Faculty of Selcuk University, with approval from the local ethic commission. Twenty-one male, white New Zealand rabbits weighing 2500-3000 grams were randomly allocated into three groups. In Group 1 (Control group, $n=7$ ), only laminectomy was performed and no treatment was given. In Group 2 (Collagen matrix group, $\mathrm{n}=7$ ), laminectomy was performed with a collagen matrix patch (DuraGen plus) applied on dura. In Group 3 (Chitin group, $n=7$ ), laminectomy was performed and chitin (SuproGel) injected on the dura.

\section{Surgical operation:}

Each rabbit was numbered from the ears and operated after 4 hours of starvation. General anesthesia was administered with injection of 35 $\mathrm{mg} / \mathrm{kg}$ ketamine hydrochloride (Ketalar, Pfizer, Istanbul) and $15 \mathrm{mg} / \mathrm{kg}$ Xylazin hydrochloride (Rompun, Bayer, Istanbul), intramuscularly. Cephazolin sodium $70 \mathrm{mg} / \mathrm{kg}$ (Sefazol, Mustafa Nevzat-Istanbul-Turkey) was given intramuscularly for prophylaxis. The lumbar region was shaved and painted with the antiseptic povidon iodine and covered with a sterile punched drape. A midline skin incision $4 \mathrm{~cm}$ in length was performed above the spinal processes of the lumbar region. The level of L5 was determined by palpation of the iliac wings. The lumbar fascia was uncovered in the midline and the paravertebral muscles were dissected bilaterally. After removal of the spinous process wih a rongeur, total laminectomy was performed at the level of L5 with a kerrison rongeur under the microscope. Ligamentum flavum and epidural fat tissue are excised. Hemorrhage was controlled by compression with sponges. The operation area was irrigated with physiological saline solution.

No additional process was applied to the animals in Group 1 whereas in Group 2 a collagen matrix (DuraGen Plus) patch was situated on the laminectomy area in an onlay fashion and in Group 3 Chitin (SuproGel) 1 cc gel was injected on the laminectomy area to cover the whole laminectomy area.

The rabbits were sacrificed six weeks after the surgery. The sacrification process was performed with sodium pentothal solution in $60 \mathrm{mg} / \mathrm{kg}$ doses (I.E Ulugay, Istanbul-Turkey).

The paravertebral region was exposed and the vertebral column including the paraspinal muscle system was resected in an en bloc fashion with an osteotome.

The tissue samples were fixated with $10 \%$ formaldehyde solution for 10 days and decalcified with $90 \%$ formic acid. After decalcification, tissue samples were processed to obtain sections of 5 micron thickness. The sections were painted with Hematoxylene-Eosin (H\&E) and Masson Trichrome (MT). Preparations were examined on the light microscope by single pathologist in a blind fashion. Fibroblast density, epidural fibrosis, arachnoidal fibrosis and inflammatory cell density were examined (Figure 1,2,3). The histopathological findings were evaluated with He and Revel criteria (12).

\section{Fibroblastic density}

Grade 1 : On 400x magnification the fibroblast count is less than 100 in every area

Grade 2 : On 400x magnification the fibroblast count is $100-150$ in every area

Grade 3 : On 400x magnification the fibroblast count is more than 150 in every area 


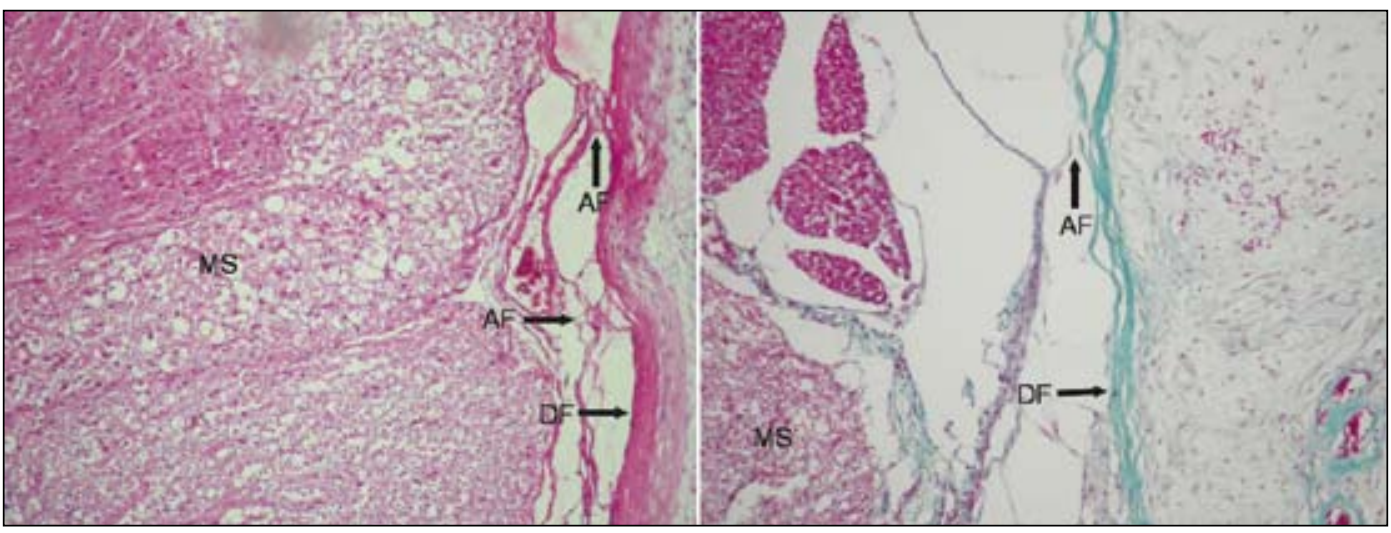

Figure 1: Photomicrographs. Left: Grade 3 epidural fibrosis demonstrated in the control group. MS: Medulla spinalis; DF: Duramater fibrosis, AF:Arachnoidal fibrosis. HEE, original magnification 40x. Right: Grade 3 epidural fibrosis demonstrated in the control group. Masson trichrome, original magnification 40x.

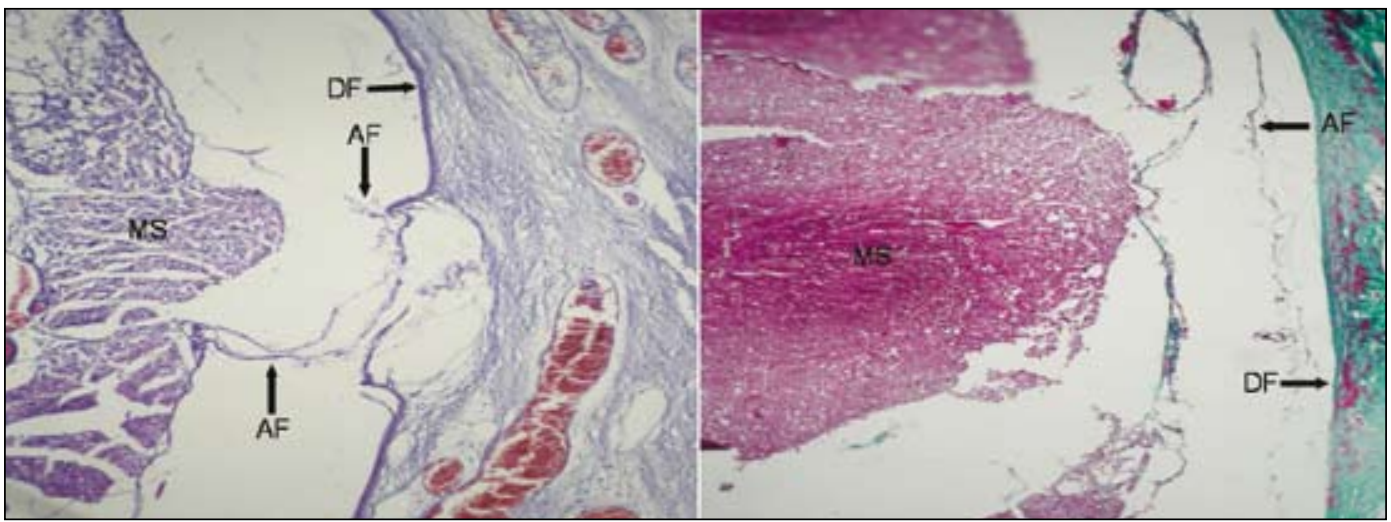

Figure 2: Photomicrographs. Left: Grade 1 epidural fibrosis demonstrated in the duragen plus group. HEE, original magnification 40x. Right: Grade 1 epidural fibrosis demonstrated in the duragen plus group. Masson trichrome, original magnification 40x.
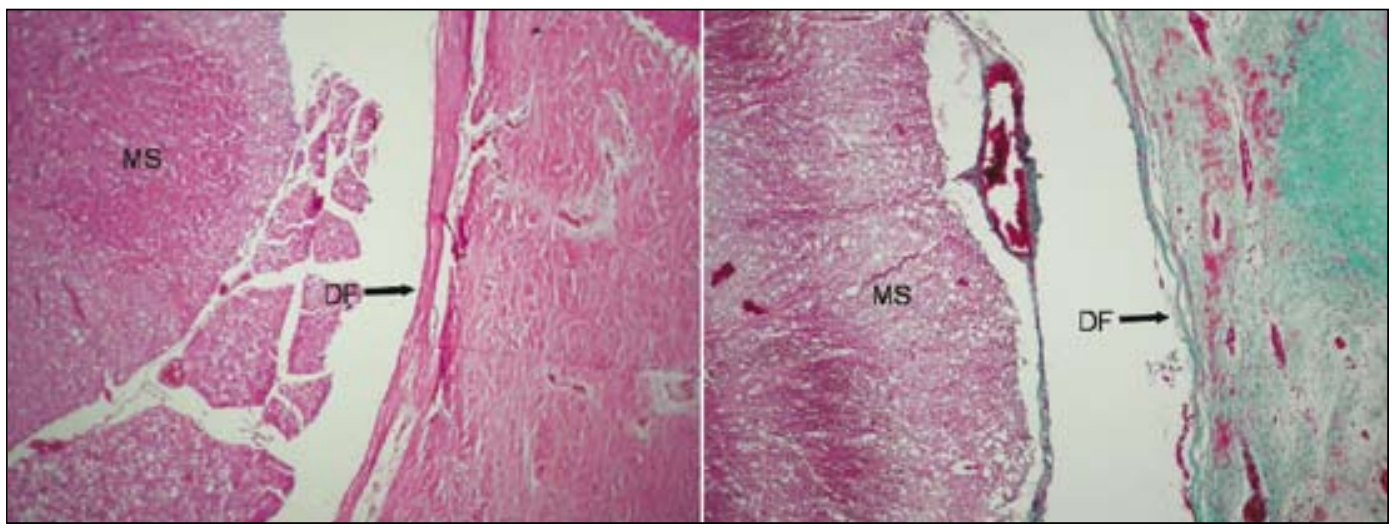

Figure 3: Photomicrographs. Left: Grade 1 epidural fibrosis demonstrated in the chitin group. HEE, original magnification 40x. Right: Grade 1 epidural fibrosis demonstrated in the chitin group. Masson trichrome, original magnification 40x.

\section{Epidural Fibrosis}

Grade 0 : Duramater with no scar formation

Grade 1 : Existence of only thin fibrous bands between scar tissue and duramater

Grade 2 : Continuous adhesions filling less than $2 / 3$ of the laminectomy space
Grade 3 : Adhesions filling more than $2 / 3$ the laminectomy space or spreading to the nerve roots

\section{Arachnoidal Fibrosis}

Grade 0 : undetectable

Grade 1 : minimal

Grade 2 : moderate 
Grade 3 : severe

\section{Inflammatory cell density}

Grade 1: On 400x magnification the inflammatory cell count is less than 100 in every area

Grade 2: On 400x magnification the inflammatory cell count is 100-150 in every area

Grade 3: On 400x magnification the inflammatory cell count is more than 150 in every area

\section{Statistical Analysis}

The data was analyzed withSPSS 13.0 for Microsoft Windows. The difference between the groups was analyzed with the Kruskal Wallis Variance Analysis Test while the difference between subgroups was analyzed with the Mann Whitney U Test. $\mathrm{p}<0.05$ was accepted as statistically significant.

\section{RESULTS}

\section{Control Group:}

Grade 3 fibroblastic density was found in 4 rabbits (57.1\%), and grade 2 in 3 rabbits $(42.9 \%)$.

Grade 3 epidural fibrosis was detected in 5 rabbits $(71.4 \%)$, and grade 2 in $2(28.6 \%)$.

Grade 3 arachnoidal fibrosis was found in 5 rabbits $(71.4 \%)$, and grade 2 in 2 rabbits $(28,6 \%)$.

Grade 2 inflammatory cell density was found in 6 rabbits $(85.7 \%)$, and grade 1 in 1 rabbit (14.3\%).

These findings are summarized in Table I.

\section{Collagen Matrix (DuraGen plus) Group:}

Grade 2 fibroblastic density was found in 3 rabbits $(42.9 \%)$, and grade 1 in 4 rabbits $(57.1 \%)$.

Grade 2 epidural fibrosis was found in 4 rabbits $(57.1 \%)$, and grade 1 in 3 rabbits (42.9\%).

Grade 2 arachnoidal fibrosis was detected in 3 rabbits $(42.9 \%)$, grade 1 in 3 rabbits $(42.9 \%)$, and grade 0 in 1 rabbit $(14.3 \%)$.

Grade 2 inflammatory cell density was found in 2 rabbits $(28.6 \%)$, grade 1 in 5 rabbits $(71.4 \%)$.

These findings are summarized in Table II.

After 6 weeks, collagen matrix (DuraGen plus) was completely resorbed in all rabbits

\section{Chitin (SuproGel) Group:}

Grade 2 fibroblastic density was found in 1 rabbit $(14.5 \%)$, and grade 1 in 6 rabbits $(85.7 \%)$.
Grade 2 epidural fibrosis was found in 2 rabbits (28.6\%), and grade 1 in 5 rabbits $(71.4 \%)$.

Grade 2 arachnoidal fibrosis was found in 1 rabbit $(14.3 \%)$, grade 1 in 3 rabbits $(42.9 \%)$, and grade 03 rabbits $(42.9 \%)$.

Grade 2 inflammatory cell density was found in 1 rabbit (14.3\%), and grade 1 in 6 rabbits $(85.7 \%)$.

These findings are summarized in Table III.

Chitin (SuproGel) was also completely resorbed 6 weeks after the surgery, without any foreign body reaction.

The collagen matrix (DuraGen plus) and chitin (SuproGel) reduced epidural fibrosis, arachnoidal fibrosis, fibroblastic density and inflammatory cell density. This reduction was statistically significant when compared with the control group $(\mathrm{p}<0.05)$. However the difference between the collagen matrix (DuraGen plus) and chitin (SuproGel) group was not statistically significant $(\mathrm{p}>0.05)$.

\section{DISCUSSION}

Postoperative epidural fibrosis growing on the dural sac and nerve roots causes neurological symptoms and this problem is still waiting a solution in spinal surgery. A relapse of epidural fibrosis in disc surgery is also known to complicate the surgery and increase morbidity $(9,14)$.

Epidural fibrosis is a part of the spinal postoperative healing process. It is seen after almost every operation at a certain rate. It takes the form of an extradural fibrotic structure and adheres to vertebra corpus, anterior disc, posterior erector spina muscles, dura and nerve roots (9).

Epidural fibrosis is one of the accepted causes of failed lumbar surgery syndrome and is responsible for $6-25 \%$ of clinical complaints. There are currently many agents used to prevent epidural fibrosis such as autologous fat grafts, polytetrafluoroethylene membrane, silastic, gelfoam, silicon-coated dacron, $\mathrm{CO}_{2}$ laser, vicryl mesh, spongostan, fibronolytic agents (plasminogen activator, urokinase), fibrin glue and antiadhesion barrier gel (ADCON-L) which is a polymer of carbohydrate $(11,16,23,26,27)$.

La Rocca et al. stated that the migration of fibroblasts (derived from the erector spina muscles) into the hematoma in the epidural space causes intensive scar formation and epidural fibrosis. Less 
Table I: Results of the Control Group According to He and Revel Criteria

\begin{tabular}{|c|c|c|c|c|}
\hline Control Group & $\begin{array}{c}\text { Fibroblast } \\
\text { Density } \\
\text { (Grade) }\end{array}$ & $\begin{array}{c}\text { Epidural } \\
\text { Fibrosis } \\
\text { (Grade) }\end{array}$ & $\begin{array}{c}\text { Arachnoidal } \\
\text { Fibrosis } \\
\text { (Grade) }\end{array}$ & $\begin{array}{c}\text { Inflammatory } \\
\text { Cell Density } \\
\text { (Grade) }\end{array}$ \\
\hline C1 & 3 & 3 & 2 & 2 \\
\hline C2 & 2 & 3 & 3 & 2 \\
\hline C3 & 3 & 2 & 2 & 1 \\
\hline C4 & 2 & 3 & 3 & 2 \\
\hline C5 & 2 & 2 & 3 & 2 \\
\hline C6 & 3 & 3 & 3 & 2 \\
\hline C7 & 3 & 3 & 3 & 2 \\
\hline
\end{tabular}

Table II: Results of the Collagen Matrix (DuraGen plus) Group According to He and Revel Criteria

\begin{tabular}{|c|c|c|c|c|}
\hline $\begin{array}{c}\text { Duragen Plus } \\
\text { Group }\end{array}$ & $\begin{array}{c}\text { Fibroblast } \\
\text { Density } \\
\text { (Grade) }\end{array}$ & $\begin{array}{c}\text { Epidural } \\
\text { Fibrosis } \\
\text { (Grade) }\end{array}$ & $\begin{array}{c}\text { Arachnoidal } \\
\text { Fibrosis } \\
\text { (Grade) }\end{array}$ & $\begin{array}{c}\text { Inflammatory } \\
\text { Cell Density } \\
\text { (Grade) }\end{array}$ \\
\hline D1 & 1 & 1 & 1 & 1 \\
\hline D2 & 1 & 1 & 0 & 1 \\
\hline D3 & 1 & 2 & 1 & 1 \\
\hline D4 & 2 & 1 & 2 & 2 \\
\hline D5 & 2 & 2 & 2 & 1 \\
\hline D6 & 1 & 2 & 1 & 1 \\
\hline D7 & 2 & 2 & 2 & 2 \\
\hline
\end{tabular}

Table III: Results of the Chitin (SuproGel) Group According to He and Revel Criteria

\begin{tabular}{|c|c|c|c|c|}
\hline $\begin{array}{c}\text { Chitin } \\
\text { (SuproGel) } \\
\text { Group }\end{array}$ & $\begin{array}{c}\text { Fibroblast } \\
\text { Density } \\
\text { (Grade) }\end{array}$ & $\begin{array}{c}\text { Epidural } \\
\text { Fibrosis } \\
\text { (Grade) }\end{array}$ & $\begin{array}{c}\text { Arachnoidal } \\
\text { Fibrosis } \\
\text { (Grade) }\end{array}$ & $\begin{array}{c}\text { Inflammatory } \\
\text { Cell Density } \\
\text { (Grade) }\end{array}$ \\
\hline S1 & 1 & 1 & 0 & 1 \\
\hline S2 & 1 & 1 & 1 & 1 \\
\hline S3 & 1 & 2 & 0 & 1 \\
\hline S4 & 1 & 1 & 2 & 1 \\
\hline S5 & 1 & 1 & 1 & 1 \\
\hline S6 & 1 & 1 & 0 & 2 \\
\hline$S 7$ & 2 & 2 & 1 & 1 \\
\hline
\end{tabular}

surgical dissection and good hemostasis are therefore suggested to decrease scar tissue density (15). Boot and Hughes reported that the laminectomy defect started to close in nearly 4 weeks and scar tissue exactly dissolved in 12 weeks in their research on epidural fibrosis on rabbits $(5,25)$. Some other reports declared that scar tissue formed in less than 8 weeks, confirming this model (2). We performed our study on rabbits in a time period of six weeks.

The basic content of epidural fibrosis is collagen produced by fibroblasts. Barbara et al. reported that collagen was the main substance that was derived 
from spinal muscles and filled the laminectomy defect and its quantity was also reported to be proportional with scar tissue (1). We would like to emphasize the collagen density results, especially in the control group, in our study.

Dura rips occur because of the adhesions of epidural fibrosis to the dura, especially in recurrent spinal surgery. A dura graft is also required in traumatic dislocation of bones to the dura and to prevent complications after the surgery of tumors that are adhesive to the dura, such as meningioma $(7,21)$. Dorsal dural defects can be sutured primarily but this is not always possible in lateral and anterior defects. Duragen, having a collagen matrix structure, is used without requiring a suture in those defects and in various disorders encountered in spinal surgery (19). Duragen encompasses fibroblasts thanks to its three-dimensional structure. This infiltration starts on the 3-4th day of the postoperative period and is completed on the 14th day and is then totally resorbed in 6 weeks $(10,22)$. No foreign body reaction was reported in clinical studies and it was also well tolerated immunologically. There was no remnant of duragen plus on histopathological examination in our study consistent with these earlier reports.

SuproGel is an anti-adhesive barrier produced from macromolecular polysaccharide and has a structure similar to human tissue $(4,18)$. It activates cell functions, improves the regeneration of traumatized tissue and provides healing (4). It is currently used as a protecting barrier in abdominal surgery to reduce the intraperitoneal adhesions. Sahin et al. compared SuproGel with other adhesion barriers in a study on rats and they reported that SuproGel was superior in terms of preventing intraabdominal adhesions (24). SuproGel acts as an antiadhesive agent by forming a biological barrier, enhancing epithelial regeneration, preventing fibroblast growth, and decreasing hemorrhage (3). This product is more than just a local adhesion barrier with these additional properties.

In another study on rats, Zeybek et al. reported that SuproGel significantly decreased peritoneal adhesions histopathologically when compared with control group (28). In our study, there were statistically significant differences between the SuproGel group and control group in all parameters. Epidural and arachnoidal fibrosis was also less in the SuproGel group than the DuraGen plus group but this difference was not statistically significant.
In conclusion, all antiadhesive agents reduce post-operative epidural fibrosis. SuproGel, being a new product, can be considered as one of the choices among various adhesion barriers. However, our results require further clinical research for clinical practice.

\section{REFERENCES}

1. Barbera J, Gonzales J, Esquerdo J, Broseta J, Barcai-Salorio JL: Prophylaxis of the laminectomy membrane. An experimental study in dogs. J Neurosurg 49(3):419-424, 1978

2. Benoist M, Ficat C, Baraf P, Chauchoix J: Postoperative lumbar epiduro-arachnoiditis. Diagnostic and therapeutic aspects. Spine 5(5):432-436, 1980

3. Biagini G: Wound management with N-Carboxybutyl chitosan. Biomaterials 12:28-31, 1991

4. Bol'shakov IN, Nasibov SM, Kulaev DV, Lopukhin IuM: Use of liquid sorbents based on chitosan for treatment of diffuse forms of peritonitis. Patol Fiziol Eksp Ter (3):49-50, 1994

5. Boot DA, Hughes SP: The prevention of adhesions after lumbar laminectomy. Adverse results of zenoderm implantations into laminectomy sites in rabbits. Clin Orthop Relat Res 215: 296-302, 1987

6. Brodsky AE: Post-laminectomy and Post-fusion stenosis of the lumbar spine. Clin Orthop Relat Res 115:130-139, 1976

7. Carl AL, Matsumoto M, Whalen JT: Anterior dural laceration caused by thoracolumbar and lumbar burst fractures. J Spinal Disord 13(5):399-403, 2000

8. Ceviz A, Arslan A, Ak HE, Inalöz S: The effect of urokinase in preventing the formation of epidural fibrosis and leptomeningeal arachnoiditis. Surg Neurol 47(2):124-127, 1997

9. Chauchoix J, Ficat C, Girard B: Repeat surgery after disc exision. Spine 3(3):256-259, 1978

10. DuraGen Instructions for Use, Integra Life Sciences Corporation, 1999

11. Gill GG, Scheck M, Kelley ET, Rodrigo JJ: Pedicle fat grafts for the prevention of scar in low back surgery. A preliminary report on the first 92 cases. Spine 10(7):662-667, 1985

12. He Y, Revel M, Loty B: A quantative model of postlaminectomy scar formation. Effects of a nonsteroidal anti-inflammatory drug. Spine 20(5):557-563, 1995

13. Jean JA, Tood LL, Bengt IL, David A, Wayne HA, Garfin SR: Preventing postlaminectomy adhesion. A new experimental model. Spine 19(16):1809-1814, 1994

14. Jeffery SR, James TR, Robert CAF, Jonathan LP, Obuchowski $\mathrm{N}$, Modic MT, deTribolet N: Assocation between peridural scar and recurrent radicular pain after lumbar discectomy: Magnetic resonance evaulation. Neurosurgery 38(4):855-863, 1996

15. LaRocca H, Mancab I: The laminectomy membrane. Studies in its evolution, carachteristics, effects and prophylaxis in dogs. The Journal of Bone and Joint Surgery 56B(3):545-550, 1974

16. Liu S, Boutrand JP, Tadie M: Use of collagen-based sealant to prevent in vivo epidural adhesions in an adult rat laminectomy model. J Neurosurg (spine) 94:61-67, 2001

17. Mertol T, Bilge B, Yücesoy K, Yüksel Z, Osün A: Correlation of epidural fibrosis and the size of lamina defect performed on operation. J Turkish Spinal Surg 6:18-20, 1995 
18. Muzzarelli R, Tarsi R, Filippini O, Giovanetti E, Biagini G, Varaldo PE: Antimicrobial properties of N-Carboxybutyl chitosan. Antimicrobial agents and chemotherapy 34(10): 2019-2023, 1990

19. Narotam PK, Van Dellen JR, Bhoola KD: A clinicopathological study of collagen sponge as a dural graft in neurosurgery. J Neurosurg 82(3):406-412, 1995

20. Ozer AF, Oktenoglu T, Sasani M, Bozkus H, Canbulat N, Karaarslan E, Sungurlu SF, Sarioglu AC: Preserving the ligamentum flavum in lumbar discectomy: A new technique that prevent scar tissue formation in the first 6 mounths postsurgery. Operative Neurosurgery 59(1): 126-133, 2006

21. Parízek J, Mĕricka P, Husek Z, Suba P, Spacek J, Nĕmecek S, Nĕmecková J, Sercl M, Eliás P: Detailed evaluation of 2959 allogenic and xenogeneic dense connective tissue grafts (fascia lata, pericardium, and dura mater) used in the course of 20 years for duraplasty in neurosurgery. Acta Neurochir(Wien) 139(9):827-838, 1997

22. P. Narotam, A. Gousseau, G. McGinn. Collagen Matrix (DuraGen) for duraplasty following cranial and spinal surgery. 35th. Canadian Congress of Neurological Sciences, Ottawa, Canada, June 2000

23. Quist JJ, Dhert WJA, Meij BP, Visser WJ, Oner FC, Hazewinkel HAW, Verbout AJ: The prevention of peridural adhesions. The Journal of Bone and Joint Surgery 80:520-526, 1998
24. Sahin M, Cakir M, Avsar FM, Tekin A, Kucukkartallar T, Akoz M: The effects of anti-adhesion materials in preventing postoperative adhesion in abdominal cavity (anti-adhesion materials for postoperative adhesions). Inflammation 30(6):244-249, 2007

25. Songer MN, Rauschning W, Carson EW, Pandit SM: Analysis of peridural scar formation and its prevention after lumbar laminotomy and discectomy in dogs. Spine 20(5):571-580, 1995

26. Tatsui CE, Martinez G, Li X, Pattany P, Levi AD: Evaluation of DuraGen in preventing peridural fibrosis in rabbits. J Neurosurg Spine 4(1):51-59, 2006

27. Yildiz KH, Gezen F, Is M, Cukur S, Dosoglu M: Mitomycin C, 5-fluorouracil and cyclosporin to prevent epidural fibrosis in an experimental hemilaminectomy model.Eur Spine J 16(9):1525-1530, 2007

28. Zeybek N, Kenar L, Yildiz F, Peker Y, Kurt B, Serdar M, Kusaslan R, Tufan T: The effect of Suprogel ${ }^{\circledR}$ - macromolecule polysaccharide - on the formation of postoperative abdominal adhesions. Balkan Military Medical Review 10:101-106, 2007 